\title{
The expression of GLUT-1 and VEGF-A mRNA in the rectal cancer patients with neoadjuvant chemoradiation
}

\author{
DOI: https:// doi.org/10.22435/hsji.v11i2.3149
}

Sri Nuryani Wahyuningrum ${ }^{1}$, Christina Hari Nawangsih Prihharsanti², Sofia Mubarika Haryana ${ }^{3}$, Ahmad Ghozali $^{4}$, Firly Putri Fardhila ${ }^{5}$

\author{
${ }^{1}$ Magelang Unit for Health Research and Development, Ministry of Health, Indonesia \\ ${ }^{2}$ Department of Radiology, dr. Kariadi Hospital, Semarang, Indonesia \\ ${ }^{3}$ Department of Histology, Faculty of Medicine, Public Health and Nursing, Universitas Gadjah Mada \\ ${ }^{4}$ Department of Anatomical Pathology, Faculty of Medicine, Public Health and Nursing, Universitas Gadjah Mada \\ ${ }^{5}$ Biomedical Sciences Study Program, Faculty of Medicine, Public Health and Nursing, Universitas Gadjah Mada \\ Corresponding author: Christina Hari Nawangsih Prihharsanti \\ Email: cnawangsih@yahoo.com
}

Received: April 16, 2020; Revised: June 11, 2020; Accepted: October 16, 2020

\begin{abstract}
Abstrak
Latar belakang: Angka kekambuhan dan resistensi pasien kanker rektum mencapai 40 persen. Kondisi tersebut bisa disebabkan karena peningkatan ekspresi GLUT-1 dan VEGF-A, serta mempengaruhi prognosis pasien. Tujuan penelitian ini adalah untuk mengetahui korelasi ekspresi mRNA GLUT-1 dan VEGF-A, serta hubungannya dengan prognosis pasien kanker rektum yang menjalani kemoradiasi.

Metode: Penelitian Kohor ini melibatkan 16 orang pasien kanker rektum lokal stadium II atau III yang menjalani kemoradiasi di RSUP Kariadi Semarang. Sampel darah intravena diambil 5 mL pada saat sebelum dan sesudah kemoradiasi. Total RNA diisolasi dari $200 \mu \mathrm{l}$ serum, kemudian dilakukan sintesis cDNA. Ekspresi mRNA GLUT1 dan VEGF-A dikuantifikasi dengan metode Livak menggunakan reference gene $\beta$-actin.

Hasil: Rata-rata ekspresi mRNA GLUT-1 menurun signifikan 2,14 kali $(P=0,044)$ dan mRNA VEGF-A menurun 1,9 kali $(P=0,03)$. Ekspresi mRNA GLUT-1 dan VEGF-A berkorelasi positif kuat dan signifikan pada saat sebelum $\left(r=0,6 ; R^{2}=0,455 ; P=0,013\right)$ dan sesudah kemoradiasi $\left(r=0,8 ; R^{2}=0,598 ; P<\right.$ 0,001). Peningkatan ekspresi $m R N A$ GLUT-1 berhubungan dengan prognosis buruk pasien, dengan resiko 18 kali lebih tinggi $(P=0,036 ; O R=18,95 \% C I=1,2-261)$. Peningkatan ekspresi $m R N A$ VEGF-A tidak berhubungan signifikan dengan prognosis pasien $(P=0,12 ; O R=9 ; 95 \% C I=0,6-123)$.

Kesimpulan: Ekspresi mRNA GLUT-1 dan VEGF-A berkorelasi positif dan saling mempengaruhi satu dengan lainnya. Peningkatan ekspresi mRNA GLUT-1 berhubungan dengan prognosis buruk pasien. Hasil penelitian ini mengindikasikan bahwa ekspresi mRNA GLUT-1 dari sampel darah berpotensi sebagai biomarker prognosis pada pasien kanker rektum yang menjalani kemoradiasi. (Health Science Journal of Indonesia 2020;11(2):92-9)
\end{abstract}

Kata kunci: kanker rektum, kemoradiasi, GLUT-1, VEGF-A, prognosis

\begin{abstract}
Background: Rectal cancer patients have 40 percent risk of recurrence and resistance, which is triggered by increasing in GLUT-1 and VEGF-A mRNA expression. This condition associate with the patients prognosis. This study aimed to determine the correlation between GLUT-1 and VEGF-A mRNA expression, and analyze its association with the rectal cancer patients prognosis who received chemoradiation.

Methods: This was a Cohort study involving 16 rectal cancer patients with stage II or III undergoing chemoradiation at Kariadi Hospital Semarang. Five milliliters of intravenous blood samples were taken before and after chemoradiation. Total RNA was isolated from $200 \mu \mathrm{l}$ of blood serum, followed by cDNA synthesis. GLUT-1 and VEGF-A mRNA expression was quantified by the Livak method using $\beta$-actin as a reference gene.

Results: GLUT-1 and VEGF-A mRNA expression decreased significantly 2.14 times $(\mathrm{P}=0,044)$ and 1,9 times $(\mathrm{P}=0,03)$, respectively. Expression of GLUT-1 and VEGF-A mRNA have a significant and strong positive correlation at before $\left(\mathrm{r}=0,6 ; \mathrm{R}^{2}=0,455 ; \mathrm{P}=0,013\right)$ and after chemoradiation $\left(\mathrm{r}=0,8 ; \mathrm{R}^{2}=0,598\right.$; $\mathrm{P}<0,001)$. GLUT-1 mRNA expression enhancement significantly associate with poor prognosis and risk 18 times of worse prognosis $(\mathrm{P}=0,036 ; \mathrm{OR}=18,95 \% \mathrm{CI}=1,2-261)$. VEGF-A mRNA expression did not associate with patient prognosis $(\mathrm{P}=0,12 ; \mathrm{OR}=9 ; 95 \% \mathrm{CI}=0,6-123)$.

Conclusion: Expression of GLUT-1 and VEGF-A mRNA have a significant and strong positive correlation. GLUT1 mRNA expression enhancement significantly associate with the poor prognosis of the rectal cancer patients. Our finding suggests that GLUT-1 mRNA expression from blood sample was potential as a biomarker to predict rectal cancer patient prognosis who received chemoradiation. (Health Science Journal of Indonesia 2020;11(2):92-9)
\end{abstract}

Keywords: rectal cancer, chemoradiotherapy, GLUT-1, VEGF-A, prognosis 
Colorectal cancer is the third most common cancer worldwide after lung and breast cancer, and it is the second leading cause of cancer-related death. Colorectal cancer prevalence is 12.8 percent and about 55 percent of cases occur in developing countries. ${ }^{1} \mathrm{In}$ epidemiological studies, the occurrence of the colon and rectal cancers is still not distinguished, because the anatomical location is adjacent and symptoms are generally almost the same. Requires further clinical and biomedical examination to differentiate colon and rectal cancer. ${ }^{2}$ About 30 percent of colorectal cancer cases were rectal cancer. Although the incidence rate is lower than colon cancer, the rate of recurrence and therapy resistance in rectal cancer is higher. Standard therapy in rectal cancer known as "trimodality therapy", consists of neoadjuvant chemoradiotherapy, surgery and adjuvant chemotherapy. There is about 40 percent of rectal cancer patients who have recurrence and resistance after treatment. ${ }^{3,4}$

Recurrence and resistance after therapy can be triggered by hypoxic conditions in the tumor microenvironment, especially in locally advanced solid tumors. Hypoxia in the tumor microenvironment is a condition of oxygen lacking supply in cells and tissues, due to uncontrolled cell proliferation, energy metabolism switching and abnormal growth of blood vessels. ${ }^{5}$ Cancer cells that have adapted with hypoxia play a role in therapy resistance through inhibition of therapeutic drug delivery and absorption by cells, and low oxygen levels reduce the effects of chemotherapy cytotoxicity. ${ }^{6,7}$ Hypoxic conditions could modify cancer cell metabolism by increase glycolysis rate and Glucose transporter-1 (GLUT1) expression, inhibit oxidative phosphorylation and induce hypoxia-inducible factor-1 (HIF-1) expression. ${ }^{8}$ Glucose transporter- 1 is a membrane cell receptor that facilitates glucose uptake by the passive transport mechanism into the cytoplasm. Cancer cells dominantly use aerobic glycolysis as the main pathway in glucose metabolism to obtain adequate energy in a fast and short time. This abnormality is known as the Warburg effect. ${ }^{9}$ The more glucose transfer into the cell, the higher GLUT-1 expression. Glucose transporter-1expression usually increases in cancer cells and associated with cancer progression. ${ }^{10}$

Hypoxia also triggers pro-angiogenesis factors expression in large numbers, such as vascular endothelial growth factor A (VEGF-A). In cancerous conditions, VEGF-A stimulates new blood vessel formation from nearby capillaries to help tumor cells obtaining adequate oxygen and nutrients. ${ }^{11}$ Vascular endothelial growth factor-A also regulates abnormal vascularization in tumor microenvironments such as excessive branching, leaky blood vessels and dead blood end-vessels. Increasing VEGF-A expression is associated with carcinogenesis, metastasis and tumor cell invasion. Vascular endothelial growth factor-A also becomes a cytokine marker of poor prognosis after radiotherapy. ${ }^{12}$ Increasing GLUT-1 and VEGF-A expression contribute to maintain tumor microenvironment, so that cancer cells can survive, proliferate continuously, metastasis and resistant to a given therapy. ${ }^{5}$ Through this study, the authors want to determine the correlation between GLUT1 and VEGF-A mRNA expression and analyze its association with the prognosis of the rectal cancer patients who received chemoradiation.

\section{METHODS}

\section{Patients and samples}

This research used Cohort design and involved 16 patients with locally advanced rectal cancer in 2017 and 2018. Inclusion criteria of patients were having clinical tumor size, node status and metastasis (TNM) stage II or III without metastasis and history of other malignancies based on histopathological examination, colonoscopy and Magnetic Resonance Imaging (MRI) at Kariadi Hospital Semarang. The patients were given chemoradiotherapy at RSUP dr. Kariadi Semarang using capecitabine orally for chemotherapy and radiation dose were 45-50 Gy with 1.8-2 Gy fraction for 6-8 weeks.

Blood samples were taken from peripheral venous as much as $5 \mathrm{~mL}$ in the EDTA vacutainer at the time before and after chemoradiotherapy. Blood serum was isolated by centrifugation $3000 \mathrm{rpm}$ for 15 minutes. Blood serum was separated from the blood and aliquoted, then it was stored at $-80^{\circ} \mathrm{C}$ until further analysis.

\section{RNA isolation and cDNA synthesis}

Ribonucleic acid (RNA) was isolated from $200 \mu \mathrm{l}$ of serum using miRCURY RNA Isolation Kit for Biofluids (Qiagen, China), following the procedure from the manufacture's guideline. Ribonucleic acid concentration and purity were counted using Nanodrop (NanoVue Plus, GE Healthcare, Life Science). Pure RNA was eluted in RNAse-free water and stored in the $-80^{\circ} \mathrm{C}$ refrigerator. Synthesis of cDNA was carried out by reverse transcription reactions using ReverTraAce qPCR RT Master Mix with gDNA remover (Toyobo) and performed using 
a thermal cycler (Applied BiosystemsTM A248111) following the manufacturer's guidelines. The results of cDNA synthesis were stored at $-20^{\circ} \mathrm{C}$ until further analysis.

\section{Quantitative real-time PCR (qRT-PCR)}

Analysis of mRNA expression was performed using fluorescent SYBR Green (Bioline SensiFAST SYBR No-ROX kit) and samples were run on CFX96 Touch TM Real-Time PCR Detection System (BioRad, USA) in a total volume $20 \mu 1$. $\beta$-actin was used as a reference gene. The primer sequence of each mRNA was shown in Table 1 . The end result of mRNA expression in the form of a cycle of threshold $(\mathrm{Ct})$ or cycle of quantification $(\mathrm{Cq})$ was quantified using Livak's method relative quantification $\left(2^{-\Delta \Delta \mathrm{Ct}}\right)$ to obtain the fold changes.

Table 1. Primer of mRNA

\begin{tabular}{|c|c|c|}
\hline mRNA & & Primer Sequence \\
\hline \multirow[t]{2}{*}{$\beta$-actin } & Forward & 5'-CGCGAGAAGATGACCCAGATC-3' \\
\hline & Reverse & 5'-TCACCGGAGTCCATCACGA-3' \\
\hline \multirow[t]{2}{*}{ GLUT-1 } & Forward & 5'-TCTGGCATCAACGCTGTCTTC-3' \\
\hline & Reverse & 5'-CGATACCGGAGCCAATGGT-3' \\
\hline \multirow[t]{2}{*}{ VEGF-A } & Forward & 5'-GCACCCATGGCAGAAGG-3' \\
\hline & Reverse & 5'-CTCGATTGGATGGCAGTAGCT-3' \\
\hline
\end{tabular}

\section{Data analysis}

Patients characteristic is shown as total number (n) and percentage, or mean plus/minus and standard deviation, or minimal and maximal score. The normality data was analyzed using $\mathrm{P}$ value from Shapiro-Wilk. The mean difference before and after treatment were analyzed using Wilcoxon ranktest. Correlations between variables were analyzed using Spearman's rank correlation. The association of GLUT-1 and VEGF-A mRNA expression to the patient's characteristic was assessed using $\chi^{2}$ test (Chisquare, Fisher's exact test). The association power was evaluated with Odds Ratio (OR) equivalent to the 95\% Confident Interval (CI). Statistically significant was regarded when $\mathrm{P}$-value $<0,05$.

This study has approved by Medical Faculty of Diponegoro University and Kariadi Hospital Ethics Committee number 14/EC/ FK-RSDK/I/2017, then continued by the Medical, Public Health and Nursing Faculty Ethics Committee, Universitas Gadjah Mada Ref No KE/FK/1008/ EC/2018. All respondents approved the informed consent before register in this research.

\section{RESULTS}

\section{Clinicopathological characteristics of the patient}

Patient's clinicopathological characteristics were shown in Table 2. Patients were dominated by males, with an average age was 47 years. Based on anatomical pathology results, tumor differentiation mostly good, with the depth of tumor invasion (T stage) mostly at T3-T4 stage which means that tumor cells were invaded the visceral surface of the peritoneum. Tumor spreading to regional lymph nodes (N1-N2) occurs in majority of patients. The average early carcinoembryonic antigen (CEA) level exceeds the normal range $(>5 \mathrm{ng} / \mathrm{mL})$. Carcinoembryonic antigen is one of the blood-based biomarkers that used to determine the prognosis of the rectal cancer patient.

Table 2. Patient's clinicopathological characteristics

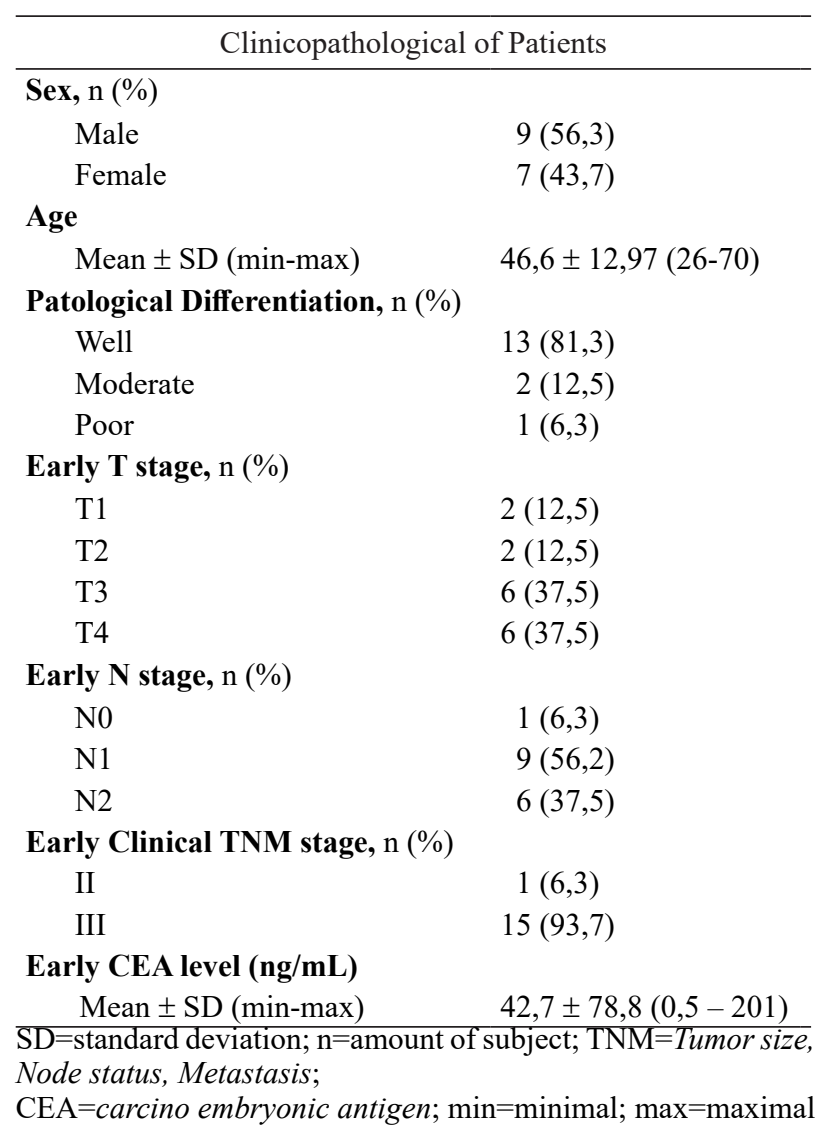

\section{Mean difference of GLUT-1 and VEGF-A expression}

Expression of GLUT-1 and VEGF-A mRNA were observed before and after chemoradiation. The results were shown in Figure 1. 

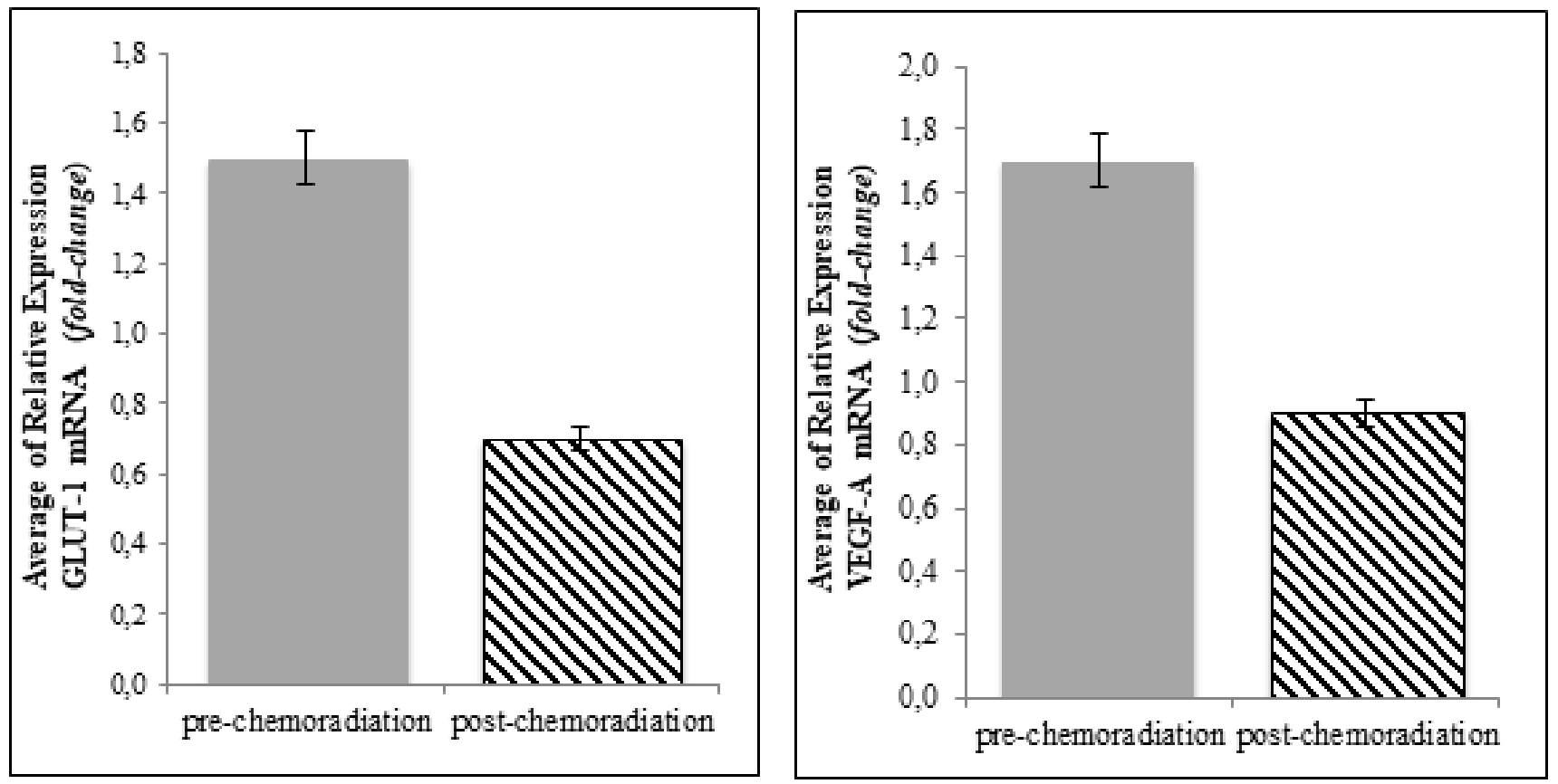

Wilcoxon signed ranks test, $*$ P-value significant $<0,05$

Figure 1. Average difference of GLUT-1 (left) and VEGF-A (right) mRNA relative expression at before and after chemoradiation

Based on average difference analysis, GLUT-1 mRNA relative expression significantly decreased 2,14 times after chemoradiation $(\mathrm{P}=0,044)$. Meanwhile VEGF-A mRNA relative expression also significantly decreased 1.9 times after chemoradiation $(\mathrm{P}=0,03)$.

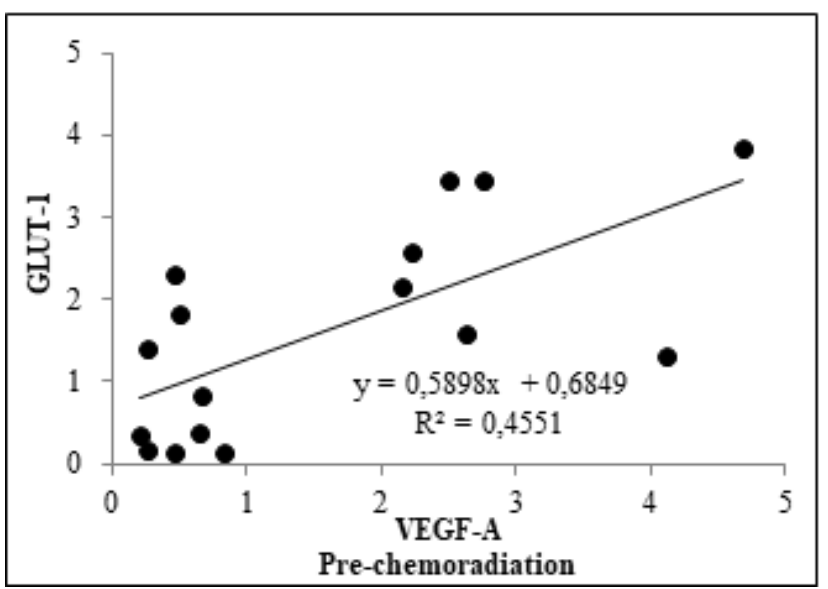

\section{Correlation between GLUT-1 and VEGF-A mRNA expression}

Based on mRNA expression in each patient, the correlation of GLUT-1 and VEGF-A mRNA expression can be determined before and after chemoradiation. The results of correlation analysis are shown in Figure 2.

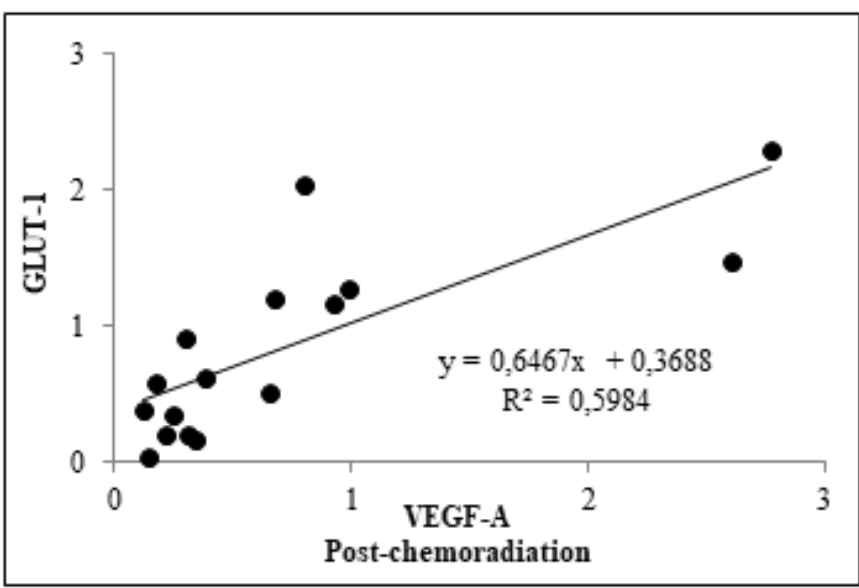

Spearman's rank correlation test $; \mathrm{r}=$ coefficient of correlation; $\mathrm{y}=$ equation of correlation; $\mathrm{R}=$ coefficient of determination; *P-value significant $<0,05$

Figure 2. Correlation between GLUT-1 and VEGF-A mRNA expression at the time before (left) and after (right) chemoradiation 
Based on correlation analysis, GLUT-1 and VEGF-A mRNA expression showed a significant and strong positive correlation $(\mathrm{P}<0.05 ; \mathrm{r}>0.5)$, both before and after chemoradiation. This was means that increasing or decreasing of GLUT-1 and VEGF-A mRNA expression will be affected on one each other. The more increase GLUT-1 mRNA expression, the more enhance VEGF-A mRNA expression, and vice versa. Glucose transporter-1 mRNA expression could affect 45,5 percent VEGF-A mRNA expression at before chemoradiation $\left(\mathrm{R}^{2}=0,455\right)$ and 59.8 percent at after chemoradiation $\left(\mathrm{R}^{2}=0,598\right)$.

\section{Association of GLUT-1 and VEGF-A mRNA expression with clinicopathology patient}

Association between GLUT-1 and VEGF-A mRNA expression with clinicopathology patient is shown in Table 3. There were no significant association between GLUT-1 and VEGF-A mRNA expression with sex, age, patological anatomy differentiation, early $\mathrm{T}$ stage, early $\mathrm{N}$ stage, early clinical TNM stage, and early CEA level $(\mathrm{P}>0,05)$ of rectal cancer patient. More than half of total patient with poor prognosis tend to have elevating GLUT-1 and
VEGF-A expression. Patient with poor prognosis have significantly increasing of GLUT-1 mRNA expression 18 times $(\mathrm{OR}=18 ; 95 \% \mathrm{CI}=1,2-261$; $\mathrm{P}<0,05)$. Meanwhile, increasing of VEGF-A mRNA expression did not associate significantly with patient prognosis $(\mathrm{P}>0,05)$, but majority of patient with poor prognosis have elevated VEGF-A expression.

\section{DISCUSSION}

Neoadjuvant chemoradiation as preferable therapy for stage II or III rectal cancer had proven can reduce local relapse, increase long-term survival and optimize surgery. Neoadjuvant chemoradiation in patients with a good response can reduce tumors up to 60 percent and reduce local recurrence. Some of the patients who can not respond to this therapy usually show a worse prognosis. ${ }^{13}$ Poor prognosis, resistance and relapsing are associated with the presence of hypoxic conditions in the tumor microenvironment. Hypoxic conditions are related to genomic instability, metastases, sustaining proliferative signaling, avoiding immune destruction, inducing angiogenesis and deregulating cellular energetics. ${ }^{14}$

Table 3. Association of GLUT-1 and VEGF-A mRNA and clinicopathology characteristic of patient

\begin{tabular}{|c|c|c|c|c|c|c|}
\hline \multirow{2}{*}{$\begin{array}{l}\text { Clinicopathology } \\
\text { characteristics }\end{array}$} & \multicolumn{2}{|c|}{$\begin{array}{c}\text { GLUT-1 mRNA Expression } \\
\mathrm{N}(\%)\end{array}$} & \multirow{2}{*}{$\begin{array}{c}\text { OR }(95 \% \mathrm{CI}) \\
\mathrm{P}\end{array}$} & \multicolumn{2}{|c|}{$\begin{array}{c}\text { VEGF-A mRNA Expression } \\
\text { N (\%) }\end{array}$} & \multirow{2}{*}{$\begin{array}{c}\text { OR }(95 \% \mathrm{CI}) \\
\mathrm{P}\end{array}$} \\
\hline & Decrease & Increase & & Decrease & Increase & \\
\hline \multicolumn{7}{|l|}{ Sex } \\
\hline Male & $3(33,3)$ & $6(66,7)$ & $1,2(0,1-10,7)$ & $4(44,4)$ & $5(55,6)$ & $0,5(0,3-0,9)$ \\
\hline Female & $2(28,6)$ & $5(71,4)$ & 0,63 & $0(0)$ & $7(100)$ & 0,09 \\
\hline \multicolumn{7}{|l|}{ Age } \\
\hline$<50$ years & $2(20)$ & $8(80)$ & $0,2(0,03-2,3)$ & $1(10)$ & $9(90)$ & $0,1(0,01-1,5)$ \\
\hline$\geq 50$ years & $3(50)$ & $3(50)$ & 0,3 & $3(50)$ & $3(50)$ & 0,12 \\
\hline \multicolumn{7}{|l|}{ Differentiation } \\
\hline Well & $3(23)$ & $10(77)$ & $0,1(0,01-2,3)$ & $3(23)$ & $10(77)$ & $0,6(0,04-9,1)$ \\
\hline Moderate - Poor & $2(66,7)$ & $1(33,3)$ & 0,21 & $1(33,3)$ & $2(66,7)$ & 0,61 \\
\hline \multicolumn{7}{|l|}{ Early T Stage } \\
\hline $\mathrm{T} 1-\mathrm{T} 2$ & $1(25)$ & $3(75)$ & $0,67(0,05-8,6)$ & $0(0)$ & $4(100)$ & $1,5(1-2,2)$ \\
\hline $\mathrm{T} 3-\mathrm{T} 4$ & $4(33,3)$ & $8(66,7)$ & 0,63 & $4(33,3)$ & $8(66,7)$ & 0,52 \\
\hline \multicolumn{7}{|l|}{ Early N Stage } \\
\hline N0 & $0(0)$ & $1(100)$ & $1,5(1-2,1)$ & $0(0)$ & $1(100)$ & $1,3(1-1,8)$ \\
\hline $\mathrm{N} 1-\mathrm{N} 2$ & $5(33,3)$ & $10(66,7)$ & 0,68 & $4(26,7)$ & $11(73,3)$ & 0,75 \\
\hline \multicolumn{7}{|l|}{ Early Clinical TNM Stage } \\
\hline II & $0(0)$ & $1(100)$ & $1,5(1-2,1)$ & $0(0)$ & $1(100)$ & $1,4(1-1,8)$ \\
\hline III & $5(33,3)$ & $10(66,7)$ & 0,69 & $4(26,7)$ & $11(73,3)$ & 0,75 \\
\hline \multicolumn{7}{|l|}{ Early CEA Level } \\
\hline Normal $(\leq 5$ ng/mL) & $2(50)$ & $2(50)$ & $3(0,3-31)$ & $2(50)$ & $2(50)$ & $5(0,4-59)$ \\
\hline Elevated( $>5$ ng/mL $)$ & $3(25)$ & $9(75)$ & 0,36 & $2(16,7)$ & $10(83,3)$ & 0,24 \\
\hline \multicolumn{7}{|l|}{$\begin{array}{l}\text { Prognosis after } \\
\text { chemoradiation }\end{array}$} \\
\hline Good & $4(66,7)$ & $2(33,3)$ & $18(1,2-261)$ & $3(50)$ & $3(50)$ & $9(0,6-123)$ \\
\hline Poor & $1(10)$ & $9(90)$ & $0,036^{*}$ & $1(10)$ & $9(90)$ & 0,12 \\
\hline
\end{tabular}

Chi-square test (Fisher's exact test) *P-value significant $<0,05$

$\mathrm{OR}=$ Odds Ratio $\mathrm{CI}=$ confident interval 
Hypoxic conditions drive tumor cells to modify cellular energetic metabolism pathways to survive. Deregulating energy metabolism are needed by cancer cell to obtain adequate nutrition in a stressful environment due to oxygen lack. In normal condition, the normal cell uses oxidative phosphorylation to produce energy, meanwhile under hypoxic conditions, cancer cells switch cellular energetics turn into aerobic glycolysis. Aerobic glycolysis produces only 2 ATP molecules, while oxidative phosphorylation produces 36 ATP molecules. Aerobic glycolysis produces less energy but tends to be faster than oxidative phosphorylation to response increasing energy requirements of cancer cells. Cancer cells need energy in a fast time and large amounts to support fast cell growth and continuous proliferation. ${ }^{9}$

Cancer cells need large amounts of glucose to produce ATP for energy metabolism. Glucose enters the cell by diffusion via glucose transport protein in the cell membrane, which is known as the glucose transporter (GLUT) family. The high demand of for glucose could increase GLUT expression, mainly GLUT-1. Glucose transporter-1 regulates glucose concentration gradient and ensures adequacy for energy metabolism. ${ }^{15}$ Its expression increases in various types of solid tumors and associated with tumor aggressiveness, cancer stage and poor prognosis in cancer patients. Increasing of GLUT-1 expression also correlates with cancer cell metastases to lymph nodes. ${ }^{16}$ In mouse animal model, increasing of GLUT1 expression associate with resistance to multiple anti-cancer therapies, including chemotherapy drug vincristine.${ }^{17}$ In this study, increasing GLUT-1 mRNA expression associate with poor prognosis in rectal cancer patients. Our result in line with Brophy et al. ${ }^{18}$ Study, which show increase in GLUT-1 expression associate with poor response to chemoradiation and is correlated with a worse prognosis. Tumors with GLUT-1 negative have 70 percent probability of good response to therapy, whereas tumors with GLUT-1 positive only have 31 percent well response. Glucose transporter-1 is potential to be a good predictive biomarker for chemoradiation response in rectal cancer. This study has limitation in small amount of subject sample, so we suggest more amount of subject sample by massive examination will obtain a more precise result.

In this study, we also observe the relationship of VEGF-A mRNA expression with patients prognosis. We did not find any significant association statistically, nevertheless based on the amount of patients we find a tendency that patients with poor prognosis have to elevate VEGF-A mRNA expression. Based on Buka et al. ${ }^{19}$ study, elevating VEGF expression is correlated with poor prognosis and a high incidence of liver metastases. Vascular endhotelial growth factor-A expression increase in 50 percent of patients of colorectal cancer and associate with cancer cell metastases to lymph nodes and others organ. Its expressions were found very high in adenocarcinoma, but lower in normal colorectal mucosal tissue. Vascular endhotelial growth factor-A is a heparin-binding glycoprotein, the most potent proangiogenesis cytokines of tumor cells. Angiogenesis enables tumor cells to enter the circulation system and metastasis. Vascular endhotelial growth factor-A induces new blood vessel formation and capillaries by increase endothelial cell permeability to support cancer tissue growth rapidly. Decreasing of VEGF-A mRNA expression after chemoradiation was used as a marker for increasing patient survival rate. ${ }^{20}$ High expression of VEGF-A associate with tumorassociated macrophage (TAM), which plays a role in tumor microenvironment remodeling after radiation or chemotherapy, so that tumor cells become resistant to the therapy. ${ }^{21}$

This study also showed a significant positive correlation between GLUT-1 and VEGF-A mRNA expression. Glucose transporter-1 plays a role in mediating glucose uptake as an energy source for cancer cells, while VEGF-A initiates angiogenesis to obtain oxygen supply and nutrients delivery to the tumor microenvironment. ${ }^{22}$ Vascular endhotelial growth factor-A could increase GLUT-1 expression by influencing translocation of transporters in the cytoplasm to the plasma membrane. ${ }^{23}$ Correlation between GLUT-1 and VEGF-A molecularly involves phosphatidylinositol 3-kinase/Akt (PI3K/Akt) pathway activation. Phosphatidylinositol 3-kinase/ Akt pathway becomes over-reactive in tumor conditions and triggers other pathway responses to support tumor cell progression, growth and proliferation to increase resistance and motility of tumor cells. The activation of the PI3K/Akt pathway responsible for radiation therapy resistance because it can modify oncogenes expression to optimize cancer cells growth. ${ }^{24}$ Phosphatidylinositol 3-kinase/Akt pathway regulates glucose entry through cell surface and GLUT-1 activity. Activation of the PI3K/Akt pathway also induces VEGF-A expression through activation of HIF-1 $\alpha$ (hypoxia-induced factor). Likewise, VEGF-A can activate PI3K/Akt pathway to protect cancer cells from radiation. ${ }^{25}$ Inhibition of the PI3K/Akt pathway can reduce GLUT-1 and VEGF-A mRNA expression. ${ }^{24}$ 
In conclusion, our results study support previous studies that GLUT-1 regulation relates one to each other with VEGF-A. Glucose transporter-1 and VEGF-A mRNA expression have a significant and strong positive correlation in the rectal cancer patients. Increasing GLUT-1 mRNA expression significantly associated with the poor prognosis of the rectal cancer patients. Our finding suggests that GLUT-1 mRNA expression from blood sample was a potential biomarker to predict the prognosis of the rectal cancer patients who received chemoradiation.

\section{Acknowledgment}

Authors gratefully thank to Dr. Ahmad Hamim Sadewa, Ph.D and Director of RSUP Dr. Kariadi Semarang. This research was supported by Community Fund Grant FK-KMK UGM (Post Graduate Scheme 2018) and Research Scholarship Fund from Ministry of Health 2018. Both supporting sources had no influence in the article contents.

\section{REFERENCES}

1. WHO.int [Internet]. Geneva: World Health Organization (WHO), Cancer; c2017-19 [updated 2018 Sep 12; cited 2019 Des 10]. Available from: URL:https://www.who.int/newsroom/ factsheets/ detail/ cancer.

2. Gaertner WB, Kwaan MR, Madoff RD, Melton GB. Rectal cancer: an evidence-based update for primary care providers. World J Gastroenterol. 2015;21(25): 7659-71 Doi: 10.3748/wjg.v21.i25.7659.

3. Lim SH, Chua W, Henderson C, Ng W, Shin JS, Chantrill L, et al. Predictive and prognostic biomarkers for neoadjuvant chemoradiotherapy in locally advanced rectal cancer. Cri Rev Oncol. Hematol. 2015;96(1):67-80. Doi: https://doi.org/ 10.1016/j.critrevonc.2015.05.003.

4. Chen M, Chen L, Xu L, Zhag J, Song X. Neoadjuvant chemoradiation for locally advanced rectal cancer: a systematic review of the literature with network meta-analysis. Cancer Manag. Res. 2019;11:741-58. Doi :10.2147/CMAR.S189445.

5. Muz B, de la Puente P, Azab F, Azab AK. The role of hypoxia in cancer progression, angiogenesis, metastasis and resistance to therapy. Hypoxia (Auckl). 2015;3:83-92. Doi :https://doi.org/10.2147/ HP.S93413.

6. Graham K, Unger E. Overcoming tumor hypoxia as a barrier to radiotherapy, chemotherapy and immunotherapy in cancer treatment. Int. J Nanomed. 2018;13:6049-58.

7. Horsman MR, Overgaard J. The impact of hypoxia and its modification of the outcome of radiotherapy. J. Radiat. Res. 2016;57 (S1):i90-i98.
8. Yu XJ, Song JC, Du J, Shi YQ, Liu YX, Shen Y. GLUT-1 and its regulating factor HIF-1a expression in epithelial ovarian tumors: GLUT-1 is associated with molecular typing and grade of epithelial ovarian cancer. Int. J. Exp. Pathol. 2017;10(4):4479-87.

9. T, Gatenby RA, Brown JS. The Warburg effect as an adaptation on cancer cells to rapid fluctuations in energy demand. Plos ONE. 2017;12(9)e0185085:114. Doi: https://doi.org/ 10.1371/journal. pone. 0185085 .

10. Chung FY, Huang MY, Yeh CS, Chang HJ, Cheng TL, Yen LC, et al. Glut-1 gene is a potential hypoxic marker in colorectal cancer patient. BMC Cancer. 2009;9(241):1-11. Doi : 10.1186/1471-2407-9-241.

11. Arcondeguy T, Lacazette E, Millevoi S, Prats H, Touriol C. VEGF-A mRNA processing, stability and translation: a paradigm for intricate regulation of gene expression at the post-transcriptional level. Nucleic Acids Res. 2013;41(17):7997-8010 Doi:10.1093/nar/gkt539.

12. Bendardaf R, El-Serafi A, Syrjanen K, Collan Y, Pyrhonen S. The effect of vascular endothelial growth factor-1 expression on survival of advanced colorectal cancer patients. Lybian J. Med. 2017;12:1-5. Doi : http://dx.doi.org/ 10.1080/19932820.2017.1290741.

13. Conde-Muino R, Cuadros M, Zambudio N, SeguraJimenez I, Cano C, Palma P. Predictive biomarkers to chemoradiation in locally advanced rectal cancer. BioMed Res. Int. 2015;921435:1-10. Doi:http:// dx.Doi.org/10.1155/ 2015/921435.

14. Al Tameemi W, Dale TP, Al-Jumaily RMK, Forsyth NR. Hypoxia-modified cancer cell metabolism. Frontiers in cell and development biology. Front. Cell Dev. Biol. 2019;7(4):1-15. Doi: 10.3389/ fcell.2019.00004.

15. Barron CC, Bilan PJ, Tsakiridis T, Tsiani E. Facilitative glucose transporters: implications for cancer detection, prognosis and treatment. Metabolism. 2016;65:124-39. doi: 10.1016/j. metabol.2015.10.007.

16. Shibuya K, Okada M, Suzuki S, Seino M, Seino S, Takeda $\mathrm{H}$, et al. Targeting the facilitative glucose transporter GLUT1 inhibits the self-renewal and tumor-initiating capacity of cancer stem cells. Oncotarget. 2015;6:651-61. Doi: 10.18632/ oncotarget.2892.

17. Trendowski M, Mitchell JM, Corsette CM, Acquafondata C, Fondy TP. Chemotherapy with cytochalasin congeners in vitro and in vivo against murine models. Invest. New Drugs 2015;33:290-9. doi: 10.1007/s10637-014- 0203-5.

18. Brophy S, Sheehan KM, McNamara DA, Deasy J, Bouchier-Hayes DJ, Kay EW. GLUT-1 expression and response to chemoradiotherapy in rectal cancer. Int. J. Cancer. 2009;125:2778-82.

19. Buka D, Dvorak J, Sitorova V, Sirak I, Voboril $\mathrm{R}$, Melichar B, et al. The changes of tumour vascular endothelial growth factor expression after neoadjuvant chemoradiation in patients with rectal 
adenocarcinoma. Contemp. Oncol. 2017;21(1):4853. Doi: http://Doi.org/10.5114/wo. 2017.66656.

20. Bendardaf R, El-Serafi A, Syrjanen K, Collan Y, Pyrhonen S. The effect vascular endothelial growth factor-1 expression on survival of advanced colorectal cancer patients. Lybian J. Med. 2017;12:1-5. Doi: http://dx.doi.org/ 10.1080/19932820.2017.1290741.

21. Wahyuningrum SN. Expression of miR-124-3p, carbohydrate kinase-like (CARKL) mRNA, and VEGF-A mRNA as markers of tumor-associated macrophage (TAM) metabolic reprogramming in rectal cancer patients at before and after chemoradiation [Thesis]. Yogyakarta: Universitas Gadjah Mada; 2019.

22. Lv X, Li J, Zhang C, Hu T, Li S, He S, et al. The role of hypoxia-inducible factors in tumor angiogenesis and cell metabolism. Genes Dis. 2017;4:19-24. Doi :http://dx.doi.org/10.1016/j.gendis.2016.11. 003.

23. Sone H, Deo BK, Kumagai AK. Enhancement of glucose transport by vascular endothelial growth factor in retinal endothelial cells. Investig. Ophthalmol. Vis. 2000;Sci 41:1876-84.

24. Yeh WL, Lin CJ, Fu WM. Enhancement of glucose transporter expression of brain endhotelial cells by vascular endhotelial growth factor derived from glioma exposed to hypoxia. Mol. Pharmacol. 2008;73:170-7.

25. Fang J, Zhou SH, Fan J, Yan SX. Roles of glucose transporter-1 and the phosphatidylinositol 3-kinase/ protein kinase B pathway in cancer radioresistance. Mol. Med. Rep. 2015;11:1573-81. 